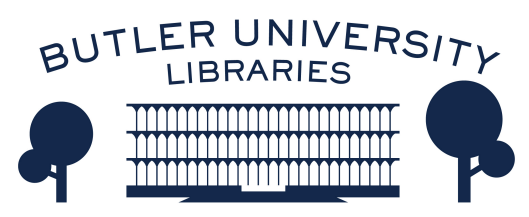

Journal of Hindu-Christian Studies

Volume 10

Article 20

January 1997

\title{
Book Review: "Kali's Child: The Mystical and the Erotic in the Life and Teachings of Ramakrishna"
}

Pravrajika Vrajaprana

Follow this and additional works at: https://digitalcommons.butler.edu/jhcs

Part of the Religion Commons

\section{Recommended Citation}

Vrajaprana, Pravrajika (1997) "Book Review: "Kali's Child: The Mystical and the Erotic in the Life and Teachings of Ramakrishna"," Journal of Hindu-Christian Studies: Vol. 10, Article 20.

Available at: https://doi.org/10.7825/2164-6279.1166

The Journal of Hindu-Christian Studies is a publication of the Society for Hindu-Christian Studies. The digital version is made available by Digital Commons @ Butler University. For questions about the Journal or the Society, please contact cbauman@butler.edu. For more information about Digital Commons @ Butler University, please contact digitalscholarship@butler.edu. 
return to the simple ethics and beliefs of world religions would ensure that people, if not necessarily in the vast numbers of today, live full and happy lives in harmony with nature. Yet as Thomas Berry, Larry Rasmussen, Rosemary Radford Ruether, and other theologians now argue, what is needed is a radically new way of looking at and living with nature, one more in tune with the findings of science and one much more critical of existing economic and social structures. If religion has an essential role to play in a grand reconstruction, it does not seem to have found one yet.

Antony Berger

Victoria

\section{Kälì's Child: The Mystical and the Erotic in the Life and Teachings of Ramakrishna. Jeffrey J. Kripal. Chicago: University of Chicago Press, 1995, xxi+386pp.}

$K \bar{A} L \bar{I}$ 'S CHILD SEEKS to uncover the inner life of the Bengal mystic Ramakrishna. The "secret talk" found in the Käthamrta (known in English as The Gospel of Sri Ramakrishna) provides the primary source material for Kripal's textual exegesis, though other, less familiar texts are also included. Through this analysis the author arrives at some provocative conclusions: Ramakrishna was essentially a conflicted Tantric whose suppressed homoerotic urges fuelled his frequent samadhis. A misogynist as the result of childhood sexual advances by village women, Ramakrishna was later sexually preyed upon by his patron Mathur and by his female and male gurus. Finally these "secrets" were systematically suppressed by the Ramakrishna Order.

Kripal writes well, brilliantly on occasion, and presents his evidence with a fine flourish. The extensive bibliography is impressive, and Kripal displays a command over a wide body of material. Considering the author's promise, why then is the book so flawed?

While the author describes himself as a "digger" who uncovers hidden material, his methodology has been more like the rogue cop who plants evidence only to "discover" it for the sake of manufacturing his case. Betraying his own bias, the author frequently uses misleading translations to prove his thesis. Examples abound, but a couple will demonstrate Kripal's technique: Ramakrishna goes into samadhi seeing an English boy who reminds him of Krishna. According to Kripal, Ramakrishna goes into samadhi seeing the boy "thrice-bent in an erotic pose", and "stunned by the cocked hips of the boy". Yet neither of the two references cited by the author mentions "cocked hips" or an erotic pose. It simply states that the boy was "tribhanga" - bent in three places. On a different tack, "māga" is translated as "bitch" - thus verifying Ramakrishna's purported misogyny - when the word is merely a colloquialism for "woman". Other distorted translations alternately transform Ramakrishna into a pederast or an onanist.

Kripal further builds his case by quoting unreliable sources. For example, Kripal describes a particularly bizarre method Ramakrishna supposedly used to control lust, but his endnote admits that he "doubts seriously" the incident ever occurred. Inexplicably, the incident is referred to again, twenty pages later, to seal his conclusion - despite his own admission that the information is probably inaccurate.

While the author decries the Ramakrishna Order's "suppression" of literature, notably the Jivanavrttänta of Ram Chandra Datta, he neglects to mention that 
the book is actually published by the Order and is in its ninth edition.

The above examples are only a sampling of the book's failings. Sadly, there are inaccuracies of one sort or another on a majority of the book's pages. Kripal's hypotheses are based upon innuendo, prejudicial translation, and cultural misjudgments.

Obviously, this approach does little to advance religious and cross-cultural understanding, and that is a larger issue at stake. Can a reductionist approach such as this offer insight into a mystic's world? In the end, Kälí's Child has value as a cautionary tale, for the reply it gives to this question is a resounding no.

Pravrajika Vrajaprana Santa Barbara

\section{India's Agony Over Religion. Gerald Larson. Albany: State University of New York Press, 1995, xiv +393pp.}

\section{LARSON FOCUSES ON India's} contemporary agony over religion as manifested in five case studies: (1) Sikhs in the Punjab; (2) Muslims in Kashmir; (3) Difficulties in developing a uniform civil code (e.g. the Shah Bano Begum case); (4) Compensatory discrimination to help "backward classes"; and (5) the Ayodhya/ BabriMasjid crisis. What makes Larson's discussion especially valuable is that he contextualizes these events in India's religious, philosophical, and cultural history stretching back some four thousand years. This gives Larson's approach a depth of understanding that is often lacking in social science studies that largely confine themselves to recent history.

Why is this book of interest to scholars in Hindu-Christian studies? Because Larson's thesis is that the Neo-Hindu reformist impulses of the Brahma Samaj, the Ramakrishnan Mission, and even the Hindu Mahasabha contain "a quasi-Protestant veneer of individualism and the privatization of religious belief" (p.285), that is in tension with what he calls the "old Indic" tradition that typified India before the coming of modernity - in which Christianity played a major role.

The first half of the book offers a comprehensive retracing of India's history. Larson argues that there is no pristine Indian essence; rather, there is a continuity of
Indian experience that may be traced through its discontinuities (p.140). That continuity is to be found precisely in the ongoing conversation (or cluster of conversations) about diverse cultural and religious values that has characterized India through the ages. India's genius has been its ability to maintain a reasonably stable community of communities over time in the context of mutually contested values. In teasing out the difference in the ongoing conversation between the pre-modern (which he calls "Old Indic") and the modern (which he calls "New Indic"), he helpfully makes use of the philosophical notion of absences $(\bar{a} b h \bar{a} v a)$. The "Old Indic" is characterized by the absence of separation between reason and experience; separation of mind (ideas) from body; psychological separation between birth and rebirth; separation of individual from collective self-identity; and theological separation between Divine and Human. Whereas the various "separations" were absent in the "Old Indic", in the modern, or "New Indic" sensibility such separations are taken for granted - so complete is the Protestantization of religion among India's ruling elite, though much less in the masses.

It is these "New-Indic" separations in conversation with the "Old-Indic" values, says Larson, that have fostered India's hybrid notion of itself as a secular state, within which its current "agonies over 